\title{
DISCARDING RELICS OF THE PAST: PATRIATION OF LAWS IN THE SOUTH PACIFIC
}

\author{
Jennifer Corrin*
}

\begin{abstract}
Drawing on Professor Angelo's work in relation to the patriation of law in Niue and Tokelau as an exemplar of best possible practice, Associate Professor Corrin argues in this article that the time has come for other small island jurisdictions to complete their own promised patriation projects. In her article Dr Corrin reviews the issues facing former British dependencies in assessing whether English law applies in their jurisdiction. Dr Corrin concludes that the situation is problematic and that the interests of the rule of law would be better fulfilled by the introduction or the completion of patriation programmes. She reviews case law from a wide range of former dependencies which demonstrate the complexities of applying the reception rule and that of the confusion that can result.
\end{abstract}

\section{INTRODUCTION}

As an essential part of the independence process, the constitutions of the small island States of the South Pacific conferred autonomous lawmaking power on the local parliament. ${ }^{1}$ What they did not do was patriate (or localise) foreign laws in place at that time. ${ }^{2}$ Instead, these laws were retained

* The University of Queensland, Executive Director, Asia Pacific Law, Centre for International, Public and Comparative Law and Associate Professor, TC Beirne School of Law. The author wishes to acknowledge the significant contribution of Professor Reid Mortensen, with whom she collaborated on related research, to this article, and whose painstaking searches at the Commonwealth Secretariat yielded access to Professor Keith Patchett's report (see below, fn 3), and to thank him for his useful comments on the draft of this article. Thanks are also due to Ms Betty Mould-Iddrisu, Director, Legal and Constitutional Affairs Division, Commonwealth Secretariat, for allowing access to Patchett's report and to Hilary McEwan, Archivist and Records Management Officer, for locating this material. The author also wishes to thank her research assistant, Ms Kavita Paw.

1 This power is usually expressed in terms of power to make laws for 'peace, order and good government'. See for example, Constitution of Kiribati, s 66(1); Constitution of Solomon Islands 1978 (UK) s 59(1).

2 The term 'patriation' was coined in Canada to describe the process of transferring constitutional power from the United Kingdom to Canada. See further David Milne, The Canadian Constitution (3ed, Lorimer, Toronto, 1991). It should be noted that the term patriation was rejected as it connotes a process involving return, and this cannot properly be used where laws originated overseas. 
in force as part of the "existing law". For the most part, these are English laws, transplanted by the British metropole. However, the administration of some island States was transferred by Britain to its former colonies, and later dominions, New Zealand and Australia (countries which have themselves had to confront the question of patriation). This resulted in a legacy of New Zealand and Australian law as well as British law.

This reliance on English (or New Zealand or Australian) law was not intended to be permanent, but only a transitional measure, to provide a body of law until laws were made locally to take its place. Since that time, the task of patriation has been sadly neglected. In many South Pacific countries a large part of the law is still derived from foreign statutes. This is not an issue unique to the South Pacific; many former colonies worldwide have a similar legacy.

Professor Anthony (Tony) Angelo is one of a small number of scholars whose work stands out as an exception in this general area of academic neglect. ${ }^{3}$ Following from his work in Mauritius and Norfolk Island, Professor Angelo took on the task of patriation in Tokelau ${ }^{4}$ and Niue. ${ }^{5}$ A patriation programme aims to ensure that all legislation is locally made. This is not simply a question of repealing the provision continuing foreign legislation in force. Taking such action without proper preparation can leave large gaps in the law. This has proved to be the case recently in Tonga, ${ }^{6}$ where the country was left without any legislation to govern areas including bankruptcy, matrimonial property distribution ${ }^{7}$ and admiralty. ${ }^{8}$ The basic approach followed by Professor

3 The work of Professor Keith Patchett must also be acknowledged. In particular, he carried out a review of legislation in Tuvalu in the 1980's. There is no published report on the exercise, which was sponsored by the Commonwealth Secretariat, but a general report by Patchett to the Commonwealth Secretariat comments on this review: Keith Patchett Inherited Imperial Statutes in Small Jurisdictions (1986) 327-8; and Inherited Imperial Statutes in Small jurisdictions, a paper delivered at the meeting of Law Officers of Small Commonwealth Jurisdictions, Vanuatu, 29 July to 2 August 1985, 61. There is also a short item mentioning it in the Commonwealth Law Bulletin: Keith Patchett, "Legal Resource Needs in Small States: the Need for New Initiatives" (1981) 7 Commonwealth Law Bulletin 1096. The Law Reform Commission of Papua New Guinea has also done some important work on point: Rob O'Regan English Statutes in Papua New Guinea, 1973, unpublished.

4 All introduced legislation was repealed by the Repeal of Laws Rules 1997 (Tokelau). See Tulafono a Tokelau (Laws of Tokelau) 2005, Legislation Roll Book: a collection of the legislation of Tokelau for 2005, volume 2 (2ed.); Tulafono a Tokelau (Laws of Tokelau) 2006-2007, Legislation Roll Book: a collection of the legislation of Tokelau for 2006-2007. Together, these two roll books form a complete collection of the laws made by Tokelau as at 1 August 2007.

5 All introduced legislation was repealed by the Interpretation Act 2004 (Niue), s 37(4). See Tau FakatufonoTohi a Niue (Laws of Niue) 2006. Legislation as at December 2006.

6 Civil Law (Amendment) Act 2003 (Tonga) repealed the reference to 'statutes of general application' in the Civil Law Act, Cap 25 (Tonga).

7 Since the passing of the Civil Law Act Amendment Act 2003 the Matrimonial Causes Act 1973 (UK) is no longer in force in Tonga; Halapua v Tonga (30 July 2004) unreported, Court of Appeal of Tonga, Burchett, 
Angelo was first to list all foreign laws extended, adopted, or generally applied to the country concerned. Those laws would then be categorised as:

- Accessible and reasonably immediately applicable. Such laws would be patriated by a reenactment or by deeming the law to have been promulgated as an Act in the country concerned;

- Of current relevance, but maladapted to the local circumstance. Such laws would be patriated either by repeal and replacement by a new enactment or by substantial amendment to the foreign law. A variation on this, identified by Professor Angelo, is foreign law that is still desired but cannot be administered in the specific country, for example, intellectual property law. In that case the foreign law would be repealed and replaced by a local Act providing, for example, that a patent or trademark registered in a specified overseas country would be enforced and subject to the same protections in the country in question; or

- Of no current relevance. Such laws would be repealed. The provision applying or adopting the foreign laws in the country concerned would also be repealed.

This article commences with an explanation of the different means by which foreign legislation remains potentially applicable in South Pacific countries. It then examines the uncertainties arising under the current regimes of those countries. Relevant case law, coming mainly from the region, but also from other parts of the Commonwealth, is analysed and used to highlight some of these uncertainties. From this foundation, the article moves on to discuss, with further reference to relevant case law, the reasons why the patriation work, such as that undertaken by Professor Angelo, is of such importance.

\section{THE COMMON LAW INHERITANCE}

As in other former British dependencies, the Common Law was introduced into the South Pacific during the colonial era. ${ }^{9}$ This included not only decisions of the English courts, that is common law and equity, but also, statute law. ${ }^{10}$ At independence, ${ }^{11}$ overseas legislation was not patriated as it should have been as part of the independence process. ${ }^{12}$ Instead, as a transitional step,

Tompkins and Salmon JJ. This case and most of the other unreported cases cited in this article can be accessed via www.pacLII.org.

8 Matangi Tonga Tonga Laws Are There to Protect the People Who Have No Power (2004) www.matangitonga.to/home/ward/htm (accessed 21 July 2004).

9 Sir Kenneth Roberts-Wray Commonwealth and Colonial Law (Stevens and Sons, London, 1966) 540-544.

10 Idem.

11 For details of the former status of the countries of the region see Ronald G Crocombe The South Pacific (5ed, University of the South Pacific SP, Suva, 1989) 231.

12 See Keith Patchett Inherited Imperial Statutes in Small jurisdictions, above n 3, 61, 62 para 7. 
it was "saved", together with common law and equity. This served to avoid a vacuum pending the creation of "local" laws by the new legislature and development of a body of case law by local courts. Some countries of the region have since taken steps to break this continued dependency on overseas laws. ${ }^{13}$ Unfortunately, others have been slow to replace foreign statutes with "homegrown" laws or even with locally enacted legislation based on foreign models. For example, Solomon Islands passed an average of eight statutes a year between 1994 and 2007.

In countries of the region that have not terminated their dependency on foreign legislation it remains potentially applicable by any or all of four different means: the act of independence, residual paramount operation, reception and incorporation. ${ }^{14}$ As these four means require separate explanation, this article will discuss each in turn.

\section{A Act of Independence}

In some former dependencies, the independence constitution derived its original legal authority from the United Kingdom legislation which brought it into effect. ${ }^{15}$ For example, in Kiribati, the Constitution is a schedule of the Independence Order made in the United Kingdom. ${ }^{16}$ This is not the case in all South Pacific countries, as some regional constitutions were made locally through a constitutional convention or similar means. ${ }^{17}$ Since their independence, other countries have discarded constitutions made in the United Kingdom and brought into force their own document. ${ }^{18}$ Through this act of autochthony they have transferred the legal source of their constitution to within their own shores. ${ }^{19}$ In countries in which the authority of the constitution is still derived from the

13 See for example, Interpretation Act 2004 (Niue), s 37(4), and Civil Law Amendment Act 2003 (Tonga), discussed further above.

14 Compare Keith Patchett, above n 3, para 7. In Niue, there is also the possibility of extension: see further notes 24 and 25.

15 See, for example, in Fiji: Fiji Independence Order 1970 (UK); Solomon Islands: Solomon Islands Independence Order 1978 (UK); Tuvalu: Tuvalu Independence Order 1978 (UK).

16 Kiribati Independence Order 1979 (UK).

17 For example, in Samoa, Nauru and FSM the constitutions were brought into force by Constitutional Convention; in Marshall Islands the constitution was brought into force by a Constitutional Convention plus referendum; in Papua New Guinea it was by Constituent Assembly; and in Vanuatu by Exchange of Notes between Governments of the United Kingdom and France, 23 October 1979.

18 For example, the Constitution of Tuvalu 1986 (Tuvalu); Constitution of the Sovereign Democratic Republic of Fiji (Promulgation) Decree 1990 (Fiji) and Constitution (Amendment) Act 1997 (Fiji). For a discussion of the challenges presented in patriating constitutions see, for example, Geoffrey Marshall Constitutional Conventions: The Rules and Forms of Political Accountability (Oxford University Press, Oxford, 1984) 180-190.

19 There has been debate as to when a former British possession can genuinely be held to have undertaken an act of autochthony and to have deliberately broken legal continuity with the UK: (Wheare 1960, 89-113; Robinson 1961). The effective patriation of the Canadian Constitution in 1982 shows that an act of 
United Kingdom, the constitution remains technically United Kingdom legislation applicable as law in that country.

\section{B Residual Paramount Operation}

The second means by which United Kingdom legislation may remain applicable in former dependencies is through residual paramount operation. ${ }^{20}$ United Kingdom legislation is applicable outside the United Kingdom if it expresses an intent to apply extraterritorially. This can arise in three different circumstances:

- where legislation has been applied to a named United Kingdom possession; ${ }^{21}$

- where legislation has been applied throughout the British Empire generally; ${ }^{22}$ and

- where legislation is applicable to the conduct of United Kingdom nationals outside the Empire. $^{23}$

Examples of all three circumstances are easy to find in the South Pacific. United Kingdom Acts of independence, such as the Kiribati Independence Order 1979 (UK) contemplate that, until repealed or amended by the local Parliament, United Kingdom legislation passed before the date of independence and expressed to apply in the country in question in one of the three ways described above, would continue in operation. ${ }^{24}$

In Niue, the Constitution also preserves the right of New Zealand to extend legislation to Niue, with the request and consent of the Niue Assembly. ${ }^{25}$ A small number of Acts have been introduced

autochthony can be undertaken peacefully and effectively, but, in that case, judicial recognition of the act of autochthony was given in advance: Re Resolution to Amend the Constitution [1981] 1 SCR 753.

20 Australian Capital Territory Law Reform Commission, Imperial Acts in Force in the Australian Capital Territory, (Government Printer, Canberra, 1974, 2; Commonwealth and Colonial Law , above n 9, 142; New Zealand Law Commission, Imperial Legislation in Force in New Zealand: Report No 1 (NZLC 1, Wellington,1987) 3; Keith Patchett Inherited Imperial Statutes in Small Jurisdictions (1986), above n 3, 318-320.

21 Commonwealth and Colonial Law, above n 9, 142; Imperial Legislation in Force in New Zealand, above n 20, 3.

22 Commonwealth and Colonial Law, ibid.

23 Reid Mortensen "Slaving in Australian Courts: Blackbirding Cases, 1869-1871" (2000) 4 Journal of South Pacific Law 7, 12-13.

24 See, for example, Kiribati Independence Order 1979 (UK) s 5.

25 Constitution of Niue 1974 (NZ) s 36(1). This provision finds a parallel in Statute of Westminster 1931 (UK) s 4, which, if ratified by their parliaments, allowed the British parliament to extend legislation to its dominions with their request and consent. It applied in New Zealand between 1947 (Statute of Westminster Adoption Act 1947) and 1986 (New Zealand Constitution Act 1986). 
in this way. ${ }^{26} \mathrm{~A}$ similar, although negatively phrased, provision was originally made in the Constitution of Cook Islands, ${ }^{27}$ but this has since been abolished. ${ }^{28}$

\section{Incorporation}

The third means by which United Kingdom legislation is applicable in regional countries is by incorporation. ${ }^{29}$ This occurs through a reference in local legislation to a United Kingdom statute, and is more usually found in the country's pre-independence colonial legislation. This differs from the practice common throughout the Commonwealth of adapting the terms of United Kingdom legislation in local lawmaking, resulting in patriation of the United Kingdom legislation. In contrast, incorporation does not separately enact United Kingdom legislation as local legislation. Rather, it involves a reference in the local statute to a United Kingdom statute by its short title, thereby making that United Kingdom statute law in the local country. An example from Solomon Islands is the Oaths $\mathrm{Act}^{30}$ which incorporates by reference section 5 of the Commissioner for Oaths Act 1889 (UK) and the Statutory Declarations Act 1835 (UK).

\section{Reception}

The fourth and most common source of applicable foreign legislation is reception. ${ }^{31}$ This is the classical method by which metropolitan law was "introduced" to an overseas possession. For United Kingdom possessions, what was received was usually English law, which includes aspects of both English judge-made law and legislation. The received legislation comprised United Kingdom legislation, including enactments of the English Parliament and of the United Kingdom Parliament, (after the unions with Scotland and Ireland) ${ }^{32}$ in force as law in England on a specified date. ${ }^{33}$

26 See, eg, Misuse of Drugs Act 1975 (NZ), extended to Niue. It is interesting to note that the Misuse of Drugs Act 1998 (Niue) purports to extend to Niue all future amendments to the Misuse of Drugs Act 1975 (NZ), even though there has been no express request or consent to each amendment.

27 See, for example, Matrimonial Property Act 1976 (NZ), extended to Cook Islands 21 April 1992.

28 Constitution of Cook Islands 1964, Art 46, abolished by the Constitution Amendment (No 9) Act 1980-1981 (CI), art 5.

29 Commonwealth and Colonial Law, above n 9, 556, 142; Imperial Legislation in Force in New Zealand, above n 20, 3; Keith Patchett, Inherited Imperial Statutes in Small Jurisdictions (1986), above n 3, 317-18.

30 Cap 23 (SI) ss 3(5) 4, referring to Commissioner for Oaths Act 1889 (UK) s 5, and Statutory Declarations Act 1835 (UK)

31 Imperial Acts in Force in the Australian Capital Territory, above n202; Imperial Legislation in Force in New Zealand, above n 20, 2-3; Patchett 1986, above n 3, 320-323; Jennifer Corrin Care "Colonial Legacies?" in Corrin Care J (ed) Sources of Law in the South Pacific (1997) 21 Journal of Pacific Studies, Suva: USP.

32 This point is doubted by Patchett who states that statutes of general application must be 'Imperial Acts': Keith Patchett "Inherited Imperial Statutes in Small Jurisdictions", above n 3, 65.

33 Commonly referred to in the region as "the cut-off date". 
United Kingdom legislation passed after this cut-off date did not apply. In contrast to statutes that apply by paramount operation, this received legislation was enacted for use in England and with no specific intent of being applied elsewhere. So long as the conditions set out in the reception rule were met, the United Kingdom legislation was deemed to be law in the relevant overseas possession. In countries administered by Australia or New Zealand an added layer of complication was involved. In those countries, the United Kingdom legislation had to be in force in the administering State or country at the cut-off date. For example, in Nauru, British statutes, "in force in the State of Queensland at the commencement of the Laws Repeal and Adopting Ordinance 192236 , were generally adopted as part of the existing law." 34

An example of a typical reception rule is that of Kiribati. This was originally set out in the Pacific Order in Council 1893 (UK) ${ }^{35}$ and then the Western Pacific (Courts) Order 1961 (UK). By virtue of section 15 of the 1961 Order, the law in force included, "the statutes of general application in force in England on the 1st day of January 1961 ... so far only as the circumstances of [Gilbert and Ellice Islands] $]^{36}$ and its inhabitants ... permit and subject to such qualifications as local circumstances render necessary."

At independence, the Kiribati Independence $\operatorname{Order}^{37}$ continued these statutes in force by providing that:

(1) ... the existing laws shall ... continue in force on and after Independence Day as if they had been made in pursuance of this Order.

(2) The existing laws and any Act of the Parliament of the United Kingdom or Order of her Majesty in Council ... shall be construed with such modifications, adaptations, qualifications and exceptions as may be necessary to bring to them into conformity with this Order.

These provisions reflect a common pattern of reception rules for former British possessions in the Pacific. ${ }^{38}$ The continuation of the legislation by local enactment in South Pacific countries in effect amounts to incorporation by reference. However, these two categories of application are best classified separately as the terms and very general nature of the incorporation carries forward the reception rules. This pattern imposes a number of conditions on the reception of United Kingdom legislation, which must be:

- of "general application";

34 Constitution of Nauru 1968 (Nauru) art 85.

35 Pacific Order in Council 1893 (UK) cl 20.

36 Now Kiribati and Tuvalu.

371979 (UK) s 5.

38 Jennifer Corrin Care "Colonial Legacies?", above n 31, 33, 43. 
- in force in the United Kingdom (and possibly an administering State or country) on a specified date (commonly referred to in the region as "the cut-off date");

- in conformity with the relevant independence Constitution;

- in conformity with Acts of the local parliament; and

- applicable to the circumstances of the former possession.

The cut-off date is not the same in all countries. For example, in Kiribati it continues to be 1 January 1961, the date set earlier in the Western Pacific (Courts) Order 1961 (UK), ${ }^{39}$ whilst in Fiji it is 2 January 1875.40

\section{E Issues Surrounding Reception}

Of the four different means by which foreign legislation may be applicable, the most complex is reception. ${ }^{41} \mathrm{~A}$ number of issues arise from the reception rules. As these issues provide compelling illustrations of some of the reasons why patriation is so urgently required, they merit further exploration before expressly discussing the importance of patriation. Some of the most difficult questions arising from the conditions imposed on reception summarised above, are as follows:

1 Lack of a definitive meaning for the phrase "statute of general application"

The phrase "general application" is not legislatively defined and is notoriously difficult to apply. Sir Alison Russell, in his guide for drafters in British colonial territories said: ${ }^{42}$

In many colonies the draftsman will encounter the phrase "a statute of general application". It is by no

means clear when an Act is or is not a statute of general application. In a sense every statute is a statute

of general application and in a sense every statute is a statute of special application.

Similarly Sir Kenneth Roberts-Wray, in his definitive work on colonial law, said that," If the phrase were offered as a novelty to a legislative draftsman today, he would disclaim responsibility for its consequences unless it were defined". ${ }^{43}$

39 Laws of Kiribati Act 1989 (Kiribati) s 1(a).

40 Supreme Court Ordinance 1875 (Fiji) s 35.

41 Australian Capital Territory Law Reform Commission, Imperial Acts in Force in the Australian Capital Territory, 1974, Canberra: Government Printer, 2; New Zealand Law Commission Imperial Legislation in Force in New Zealand: Report No 1, 1987, Wellington, NZLRC, 2-3; Keith Patchett Inherited Imperial Statutes in Small Jurisdictions (1986) 320-323; Jennifer Corrin Care "Colonial Legacies?" in Jennifer Corrin Care (ed) Sources of Law in the South Pacific (1997) 21 Journal of Pacific Studies, USP, Suva, 33.

42 Sir Alison Russell Legislative Drafting and Forms (4ed, Butterworth and Co, London,1938) 20-21.

43 Commonwealth and Colonial Law, above n 9, 556. 
The working definition offered by Russell introduced a temporal requirement into the phrase, considering it to mean, "a statute which has its roots deep down in the past", as opposed to "a modern statute enacted to meet some special modern conditions". ${ }^{44}$ Roberts-Wray, on the other hand, suggested that an Act of general application was generally taken to be one that was "of general relevance to the conditions of other countries and, in particular, not based upon politics or circumstances peculiar to England". ${ }^{45}$

In the absence of a statutory definition, regional courts have been unable to come up with a consistent test. Courts in Tonga have adopted Roberts-Wray's definition. ${ }^{46}$ However, in Indian Printing and Publishing Co $v$ Police ${ }^{47}$ the Supreme Court of Fiji stated that: ${ }^{48}$

The expression is ... used to distinguish between public statutes not necessarily binding upon all the population, eg the Companies Act or the Friendly Societies Act on the one hand and the public statutes which on the other hand are binding upon everyone eg, the Offenses against the Person Act or similar legislation.

In Vanuatu the Court of Appeal held in Harrisen v Holloway 49 that the Police Act 1964 (UK) was not an Act of general application. The court reached this conclusion on the basis of differences between the various police forces in the United Kingdom and the single force in Vanuatu, including the different modes of control and payment, the fact that Vanuatu was a republic, and the fact that Crown Immunity did not apply. Thus, the Court appeared to be of the view that to be an Act of general application, the subject matter of the Act must operate in the same way in Vanuatu and in England. It is arguable that this is more a question of whether the Act is suitable to the circumstances of the country than whether it is an Act of general applicability, although the two questions are closely related. A similar approach was taken in Solomon Islands in Mahlon $v$ Mahlon ${ }^{50}$ where it was held that the fact that the Marriage Act 1949 laid down a complicated statutory framework which only applied to England, was enough to prevent it from being an Act of general application.

A year earlier, in $R v$ Ngena, ${ }^{51}$ the Solomon Islands' High Court took a different approach to interpretation of the phrase. Faced with the question of whether the Homicide Act 1957 (UK)

44 Sir Alison Russell Legislative Drafting and Forms above n 42, 21.

Commonwealth and Colonial Law, above n 9, 556.

46 See, for example, Teta v Ulrich [1981-88] Tonga LR 127 and Tu'itavake v Porter [1989] Tonga LR 14.

47 Indian Printing and Publishing Co v Police (1932) 3 Fiji LR 142.

48 Ibid, 145

49 Harrisen v Holloway (1980-88) 1 VLR 147.

50 Mahlon v Mahlon [1984] SILR 86, 87-88.

$51 \quad R v$ Ngena [1983] SILR 1, 6. 
applied in that country. Daly CJ defined "general application" as meaning a statute "that regulates conduct or conditions which exist among humanity generally, and in a way applicable to humanity generally". This was as opposed to an Act that is "restricted to regulating conduct or conditions peculiar to or in a way applicable only to persons, activities or institutions in the United Kingdom." This adds little specificity to the requirement, but was followed by the High Court of Tuvalu in Re the Constitution of Tuvalu and of the Laws of Tuvalu Act 1987. ${ }^{52}$

$R v$ Ngena $^{53}$ was followed in the recent Solomon Islands decision in Re Noeleen Aba Miria, ${ }^{54}$ where Palmer CJ held that the Adoption Act 1958 (UK) was an Act of general application. Palmer CJ added his own refinement, defining an Act of general application as one that "deals with a subject matter which has general relevance not merely to the situation or conditions in Solomon Islands but anywhere in the world". 55

In Christian $v R,^{56}$ referred to below, the Privy Council had the opportunity recently to set its stamp on the definition of "general application." Decisions of that body are technically binding in countries where the Privy Council is still the final court of appeal, ${ }^{57}$ such as Cook Islands, Niue, Kiribati, and Tuvalu. It will be highly persuasive in other countries of the region and throughout the Commonwealth in countries that have terminated appeals to the Privy Council. Unfortunately, the Privy Council did not take up the opportunity to provide a contemporary construction of this term. Apart from making it clear that criminal statutes may be "of general application," a point that had been doubted by Professor Angelo and Fran Wright, ${ }^{58}$ but which accords with the decision in Indian Printing and Publishing Co $v$ The Police ${ }^{59}$ and obiter in $R v$ Ngena, ${ }^{60}$ it gave no guidance on the meaning of the term.

52 (1990), High Court of Tuvalu, Donne CJ.

53 R v Ngena [1983] SILR 1, 6.

54 (1 November 2007) unreported, High Court of Solomon Islands, Palmer CJ.

55 Ibid, 2.

56 Christian $v$ R [2007] AC 400 (PC).

57 See Viro $v R$ [1978] CLR 88, para 21. The Privy Council's position as court of final appeal in these former British colonies remains unaffected by the restructuring of the courts in the United Kingdom, and the establishment of the Supreme Court of the United Kingdom: sch 16 Constitutional Reform Act 2005 (UK).

58 "Pitcairn: Sunset on the Empire?" [2004] NZLJ 431, 431-432.

59 (1932) 3 Fiji LR 142, discussed above. See also $R v$ De Baun (1901) 3 WALR 1, applying the Lotteries Act 1698 (UK) and Attorney General v Edgely (1888) 9 NSWR 157, applying the Gaming Act 1802 (UK).

60 [1983] SILR 1, 6. 
There is an additional uncertainty with the phrase in that it is unclear whether it includes subordinate legislation. ${ }^{61}$ This does not appear to have been authoritatively determined by a court within the region. However, as a matter of common sense it would seem to follow that the phrase would include subordinate legislation made under the authority of an Act of general application.

2 Uncertainty as to whether "general application" requires proof and, if so, by whom

Assuming that a definition of "general application" is agreed upon, the question then arises as to whether this is a matter requiring proof or whether there is a presumption in favour of general application. Regional courts appear to have taken the latter approach. For example, in Fiji, the Supreme Court stated in Mohammed Isaac v Abdul Kadir ${ }^{62}$ that it was presumed that the Forfeiture Act 1870 (UK) was a statute of general application. Similarly, in Solomon Islands, the Debtor's Act 1869 (UK); ${ }^{63}$ the Trustee Act, 1925 (UK); ${ }^{64}$ and the Partnership Act 1890 (UK) ${ }^{65}$ have been presumed to apply. A similar approach has generally been taken in Vanuatu, where the Bankruptcy Act 1914 (UK); ${ }^{66}$ the Fatal Accidents Act 1846 (UK); 67 and the Law Reform (Miscellaneous Provisions) Act 1934 (UK), ${ }^{68}$ have also been presumed to apply. However, in $S$ v Moti, ${ }^{69}$ Lunabek suggested, obiter, that there was an onus of proof on a person seeking to rely on a British Act.

However, in other cases, even where a presumption has not been applied and the court has seen fit to embark on an enquiry into the matter, it seems to have been regarded as a matter for judicial notice, rather than a matter requiring evidence to be adduced by the parties. ${ }^{70}$ For example in Harrisen $v$ Holloway, ${ }^{71}$ judicial notice was taken of the differences between the various police forces in the United Kingdom, and the single force in Vanuatu, and of the system of control exerted

61 Subsidiary legislation, still in force in 1968, was also continued in force as part of "the existing laws of Nauru" by Art 85 of the Constitution.

62 Mohammed Isaac v Abdul Kadir (1962) 9 FLR 152.

63 KHY CO(SI) Limited and Christopher Anthony Kwan v Ling Kun Xiang, Zhao Li Oin, Guangnan Hong Co Limited and Guangdong Enterprises (Holdings) Limited [1988-9] SILR 63.

64 Allardyce Lumber Company Limited v Attorney General [1988-9] SILR 78, 97.

65 Buchanan v Wilikai [1982] SILR 123.

66 Clements v The Hong Kong and Shanghai Banking Corporation (1980-88) 1 Van LR 416.

67 Boe v Thomas (1980-88) 1 Van LR 293.

68 Idem.

$69 S$ v Moti [1999] VUSC 38

70 In Commonwealth and Colonial Law, above n 9, 546, Roberts-Wray appears to assume that applicability is a question for judicial notice. He specifically states this to be the case in relation to evidence of local circumstances that may be taken into account to qualify an Act of general application.

71 Harrisen v Holloway (1980-88) 1 VLR 147, 150. 
by the Government of Vanuatu over the police force, as opposed to the English system where the force was controlled by its own local authority.

\section{Uncertainty as to how applicability to the circumstances of the country is determined}

Even if a statute is of general application, most reception rules state that it will only be in force in so far as it is not "inapplicable to the circumstances of"72 or "so far as circumstances admit in"73 the country in which it is sought to apply it. The question then arises whether it is for the party seeking to rely on the Act to establish that it is applicable to local circumstances or whether this is a matter for judicial notice. In the context of common law, the High Court of Solomon Islands has expressed the view that the power to declare a rule inappropriate should be approached with great caution, particularly if there has been no argument on point. ${ }^{74}$ This suggests a presumption in favour of applicability, putting the onus on a party seeking to establish inapplicability to establish this. There seems to be no good reason to distinguish legislation in this respect. Moreover, the fact that the point does not appear to have been argued before or directly decided on by any court in the region itself, appears to support the view that the courts start with a general presumption in favour of applicability.

Roberts-Wray extracted from Canadian cases the principle that British statutes did not apply unless shown to be suitable; as opposed to the common law, which applied unless shown to be unsuitable. ${ }^{75}$ However, he conceded that this might not be the case in jurisdictions where common law and statute were given effect subject to exactly the same qualifications for local circumstances. ${ }^{76}$ Unfortunately, he did not go on to say what he considered the position to be in that case. The cases referred to above suggest that in the South Pacific region, applicability to local circumstances will be presumed in the same way as general applicability.

\section{Uncertainty as to changes or modifications required by local circumstances}

In some countries of the region, it has been expressly recognised that foreign legislation will require changes to fit in with the local system of law and government. Provision has been made, either in general or more specific terms, for the foreign legislation to be modified to be in accord with the local system. Provisions that specifically state the changes that are to be made to take

72 Cook Islands Act 1915 (CI), s 615; Niue Act 1966 (NZ) s 672; Tokelau Act 1948 (NZ) s 4A; Samoa Act 1921 (NZ), s 349(1). See also English Laws Act 1858 (NZ); English Laws Act 1908 (NZ) s 2; This is not invariable the case, see for example the reception rule in Solomon Islands, interpreted in $R v$ Ngena [1983] SILR $1,6$.

73 Pacific Order in Council 1893 (UK) s 20, Western Pacific Courts Order 1961 (UK) s 15.

74 Bird $v$ The Registrar of Titles [1980/81] SILR 47, 58.

75 Commonwealth and Colonial Law, above n 9, 555.

76 Idem. 
account of local conditions ${ }^{77}$ pose little problem. However, where the provision is in general terms, as in Fiji under the Supreme Court Ordinance $1875^{78}$ and in Nauru under the Custom and Adopted Laws Act $1971,{ }^{79}$ the following questions remain largely unanswered:

- At what date must the local circumstances be examined for compatibility? Is it the cut-off date, the date of the Statute sought to be applied, the time the facts in issue in the case arose, or the date when the matter comes before the court? This point does not appear to have been discussed within the region and authorities are conflicting elsewhere it the Commonwealth. ${ }^{80}$

- Are substantive changes allowed or would the need for such changes render it inapplicable? ${ }^{81}$

- How are local circumstances proved? This is similar to the question posed above about how circumstances rendering an Act inapplicable must be proved but the answer would not necessarily be the same.

- How are changes to be physically recorded?

5 Uncertainty as to whether a United Kingdom statute is excluded by local legislation and the extent to which a United Kingdom statute may be treated as applicable in part only

The reception rules make it plain that United Kingdom Acts only apply if not excluded by local legislation. This confirms that the intention at independence, even in the absence of a comprehensive patriation scheme, was that United Kingdom legislation would be repealed, either expressly or by implication, by subsequent enactments of local parliament. However, it is not always plain whether there has been such an exclusion. Similarly, if there is a local Act relating to a particular area, but that Act does not address a particular situation, the question arises whether parts of the United Kingdom Act may be applied to fill in the gap, or whether the local Act is to be taken to have repealed the United Kingdom by necessary implication. There are arguments both ways on this. In support of the admissibility of part of a United Kingdom Act is the fact that such Acts are

77 For example, the Cook Islands Act 1915 (NZ) ss 622-640A; New Zealand Laws Act 1966 (Cook Islands); Constitution (Adaptation and Modification of Existing Laws) Orders (SI), LN 46A/1988; (No 2) Order LN 88/1988; Niue Act 1966 (NZ) ss 679-705; New Zealand Laws Act 1979 (Niue).

78 Section 24.

79 Section 5(2).

80 See the cases discussed in Commonwealth and Colonial Law above n 9, 546-547.

81 See above for a discussion of the requirement that an Act be applicable. This question has been answered in Tuvalu, where the Laws of Tuvalu Act 1987 has been interpreted as only authorising changes of a formal and non-substantial nature: In the Matter of the Constitution of Tuvalu and of the Laws of Tuvalu Act 1987 (1990) unreported, High Court of Tuvalu, Donne CJ. 
often stated to be in force, "only so far as"82 or "so far only as"83 no other provision is in force in the country in question. This could be taken to suggest that part of an Act may be applied.

This was the approach that has been taken in several regional cases. In Joli $v$ Joli, ${ }^{84}$ the Vanuatu Court of Appeal seems to have taken a particularly liberal approach to bridging gaps. It was held that although Parts I and II of the Matrimonial Causes Act of Vanuatu ${ }^{85}$ made comprehensive provision for divorce and nulity and Part III made broad provision for maintenance and alimony, it could not be seen as "evidencing a Parliamentary intention to completely cover the field in relation to ancillary matters" as it had failed to provide a power to adjust proprietary interests. Similarly, in Harry v Kalena Timber Company Limited, ${ }^{86}$ the Court of Appeal of Solomon Islands held that the Law of Property Act 1925 (UK) and in particular s. 81(1), formed part of the law of Solomon Islands. This decision was made despite the fact that the Lands and Titles Act of Solomon Islands makes comprehensive provision in relation to land. ${ }^{87}$ More recently, the Sexual Offences Act 1956 (UK) was held to be in force in Pitcairn in spite of the fact that the Justice Ordinance 1966 (Pitcairn) made provision for punishment of the same offence, but with lesser penalties attached. ${ }^{88}$

Presumably, application of part of a foreign Act is only allowed if the omission to deal with the point in question was inadvertent. This is as opposed to the position where the local Parliament had intended to "cover the field" and had deliberately omitted to provide for the matter in question, thereby implicitly directing that the United Kingdom legislation should not apply. ${ }^{89}$ The problem is of course that it may be difficult to ascertain, at least without a full legal and social inquiry, whether

82 See, for example, Civil Law Act Cap 25 (Tonga) s 4.

83 See, for example, Judicature Ordinance 1979 (Pitcairn) s 14(2).

84 (7 November 2003) unreported, Court of Appeal of Vanuatu, Lunabek CJ, Robertson, Von Doussa, Fatiaki, Saksak, and Treston, JJA. This case is discussed further in Jennifer Corrin and Don Paterson Introduction to South Pacific Law, (London; New York: Routledge-Cavendish 2007) 38 This approach appears to have been followed in Tonga: see Miller v Friendly Fishing (9 December 2002) unreported, Supreme Court of Tonga, Ford J, where it was noted, obiter, that parts of the Insolvency Act 1986 (UK) had been applied in relation to bankruptcy petitions.

85 Cap 192.

86 [2001] 3 LRC 24. See also Korean Enterprises Ltd and the Premier of Guadalcanal Province v Shell Company (Pacific Islands) Ltd (13 December 2002) unreported, Court of Appeal, Solomon Islands, Slynn $\mathrm{P}$, McPherson and Williams JJA.

87 Cap 133.

88 The maximum penalty for the relevant offences was 100 days imprisonment: see, for example, ss 82 , 87 and 88.

89 See for example, Korean Enterprises Limited and the premier of Guadalcanal Province $v$ Shell company (Pacific Islands) Limited (13 December 2002) unreported, Court of Appeal, Solomon Islands, Slynn P, McPherson and Williams JJA. 
an omission is deliberate. Prevailing circumstances and attitudes in South Pacific countries may be very different from those in former metropoles. This was the point unsuccessfully advanced in Joli $v$ Joli, ${ }^{90}$ discussed above, where it was argued that provision for matrimonial property settlement had been omitted from the local Act due to the fact that many citizens in Vanuatu would not require such provision on dissolution of marriage.

In the wider Pacific region, on the other hand, it has been held that it is not permissible to select a particular provision from a United Kingdom Act that is unsuitable to be applied in its entirety. In the Australian case of Quan Yick v Hinds, ${ }^{91}$ it was held that if an Act is generally inapplicable, individual sections, which are not in themselves objectionable, cannot be selected for use.

A similar problem may arise where there is no local legislation on point. This does not necessarily mean, as the Court of Appeal appeared to assume in the Pitcairn case, ${ }^{92}$ that the gap should be filled by reference to an Act of general application. It may be that because redress or, in criminal cases, punishment, is not deemed appropriate in the circumstances of the country.

\section{F Country Specific Issues}

1 Uncertainty as to where United Kingdom statutes rank in relation to other sources of law in Solomon Islands

In Solomon Islands another problem exists in relation to the application of United Kingdom Acts in force under the reception rule and Acts of residual paramount operation. The term "Act of Parliament", as used in that part of the Constitution that deals with sources of law, ${ }^{93}$ has been interpreted as meaning an "Act of Parliament of Solomon Islands", and not to include an "Act of Parliament of the United Kingdom". ${ }^{94}$ The consequence of this is that the paragraph which states that customary law shall not apply if inconsistent with an Act of Parliament, ${ }^{95}$ does not make customary law subject to United Kingdom Acts. This raises the question of what happens where customary law and Acts of United Kingdom conflict. In $K v T^{96}$ it seems to be suggested that the

90 [2003] VUCA 27.

91 (1905) 2 CLR 345. This case was distinguished by the Privy Council in Christian v R, above $\mathrm{n} 56$, but in relation to whether the absence of a right of appeal made an Act unsuitable to reception.

$92 R v$ Christian [2006] 4 (Pitcairn Island Court of Appeal (PICA) LRC 74 para 40.

93 Constitution of Solomon Islands 1978 (UK) sch 3.

$94 \quad R v$ Ngena [1983] SILR 1; Kv T [1985/86] SILR 49.

95 Sch 3, para 3(2).

$96 K v T$ [1985-86] SILR 49. 
two sources rank equally. In that case, public policy dictated that the principle in the United Kingdom Act should prevail. ${ }^{97}$

\section{Uncertainty as to whether United Kingdom statutes apply to everyone in Vanuatu}

Prior to independence, Vanuatu, then known as New Hebrides, was a condominium, governed by the United Kingdom and France. British laws applied to British citizens and other foreigners who opted to come under British jurisdiction. Similarly, French laws applied to French citizens and optants. There was no provision for British or French laws to apply to the indigenous population. Since independence, British and French laws remain in force ${ }^{98}$ and in Joli $v$ Joli $^{99}$ the Court of Appeal of Vanuatu held that "the law in force immediately after independence, whether derived from French law or English law or otherwise" was "law of general application to everyone within the Republic equally without distinction based on nationality or ethnic origin". This results in a position where a person may be subject to both laws. What happens in the case of conflict is unclear, but it may be that parties may opt for which law they have application to. In Mouton $v$ Selb Pacific Limited ${ }^{100}$ it appears to have been assumed that French laws would automatically apply to French citizens and optants, and, by implication, that English laws would automatically apply to British nationals and optants. Further, the court appears to have been of the view that French law would automatically apply where a document in French required interpretation. Similarly, in Newman $v$ Ah Tong, ${ }^{101}$ in a dispute surrounding the administration of a deceased's estate, the fact that the will was in English was assumed to mean that English law would apply. However, in Banga $v$ Waiwo $^{102}$ it was held that parties, presumably the Plaintiff in the first instance, could choose to proceed under English or French laws incorporated in to the law of Vanuatu. ${ }^{103}$ In criminal proceedings the choice would be made by the Public Prosecutor. ${ }^{104}$ This view is supported by Pentecost Pacific Ltd and Phillipe Pentecost v Palene Hnaloane ${ }^{105}$ where the Court of Appeal held that a choice between French and English law would "be decided according to the nationality of the

97 It should be noted that there are dangers in viewing plural laws purely in hierarchical terms see further Lauren Benton Law and Colonial Cultures: Legal Regimes in World History, 1400-1900 (Cambridge University Press, Cambridge, 2002) 8.

98 Constitution of Vanuatu 1980, art 95(2).

99 Joli v Joli (7 November 2003) unreported, Court of Appeal of Vanuatu, Lunabek CJ, Robertson, Von Doussa, Fatiaki, Saksak, and Treston, JJA.

100 Mouton v Selb Pacific Limited (13 April 1995) unreported, Supreme Court of Vanuatu, Vaudin d'Imecourt.

101 Newman v Ah Tong (13 November 2007) unreported, Supreme Court of Vanuatu, Tuohy J.

102 See also Banga v Waiwo (17 June 1996) unreported, Supreme Court of Vanuatu, d'Immecourt CJ.

103 Ibid 9.

104 Ibid 7.

105 Pentecost Pacific Ltd. and Phillipe Pentecost v Palene Hnaloane (1984) 1 VLR 134. 
defendant", which in that particular case was French law. The exact meaning of this ruling is far from clear, but at the very least, it would appear that the Court of Appeal regarded nationality of the parties to be a ruling factor.

The relationship between British and French legislation and customary law is also unclear. The constitution provides that British and French laws shall continue in force subject to certain conditions and "wherever possible taking account of custom". This appears to mean that if there is conflict between those laws the court should do its best to apply British or French law in a way which is consistent with custom. However, in Banga $v$ Waiwo $^{106}$ the Supreme Court seemed to suggest that customary law would only be taken into account if there was no written law on point. Until there is express authority on both these points, the position remains in doubt. ${ }^{107}$

\section{IMPORTANCE OF PATRIATION}

The practical and current importance of patriation was brought to the fore recently in Christian $v$ $R .{ }^{108}$ In that case, seven men were charged under the Sexual Offences Act 1956 (UK). The question arose as to whether that statute was in force in Pitcairn. The Privy Council, upholding the decision of the Pitcairn Islands Court of Appeal, answered this question in the affirmative. ${ }^{109}$ As that case and the other decisions discussed in this article illustrate, apart from the symbolic significance of patriation, there are compelling reasons for regarding this as a priority for regional reform. Some of the main reasons will now be discussed.

\section{A Rule of Law}

From a broad perspective, the failure to patriate laws has implications for the rule of law. The need to bolster, what is currently a particularly fragile concept in many parts of the region, gives further weight to the arguments in favour of patriation. A coherent, open and effective legal system is requirements of an effective rule of law. ${ }^{110}$ Four related features of the current legislative regime currently hamper this: uncertainty, lack of notice, inaccessibility and antiquation. These will now be separately discussed.

106 Banga $v$ Waiwo [1996] VUSC 5, 9.

107 See further Jennifer Corrin "Bedrock and Steel Blues: Finding the Law Applicable in Vanuatu" (1998) 24 Commonwealth Law Bulletin 594.

108 Christian $v R$, above $\mathrm{n} 56$.

109 Idem. That decision is likely to be treated as binding in Cook Islands, Niue, Kiribati, and Tuvalu, where the Privy Council is still the final court of appeal (see further Jennifer Corrin and Don Paterson Introduction to South Pacific Law (2 ed, 2007), Chapter 11), and will be persuasive in other countries of the region.

110 Lon L Fuller "The Morality of Law" (Yale University Press, New Haven, 1968) 39; John Rawls "A Theory of Justice" (Harvard University Press, Cambridge, 1972) 235. 


\section{B Uncertainty}

A vital requirement of the rule of law is the need for legal certainty. The uncertainties that surround the application of United Kingdom legislation, discussed above appear to provide a compelling argument in favour of patriation. However, Roberts-Wray expressed the opinion that, in spite of the uncertainty as to the meaning of "general application", this had not caused difficulties in countries forced to apply the reception rules. The Privy Council in Christian $v R^{111}$ repeated this sentiment and referred to Lord Denning's description of the phrase as a "wise provision". ${ }^{112}$ Although the source of these opinions lends them immense weight, this is not accepted to be the case. ${ }^{113}$ As Allott notes in the context of British African territories, "seldom has a phrase given rise to so much difficulty, or been interpreted in so many different senses by the judges." 114 This has resulted in different decisions about the applicability of the same statute in different countries of the Commonwealth. For example, the Solomon Islands courts have held that the Limitation Act 1939 (UK) is of "general application", ${ }^{115}$ whereas the Limitation Act 1933 (UK) was held not to apply in Jamaica. ${ }^{116}$ Although different decisions on the applicability of the same Act in different countries may be justified on the basis that the circumstances pertaining in those countries may differ, this means that decisions from other Commonwealth countries cannot be relied upon to settle conclusively the question of the application of other United Kingdom statutes in any other country.

On occasion, the phrase has even given rise to different decisions in the same country. In Re Noeleen Aba Miria, ${ }^{117}$ Palmer CJ had the embarrassing task of explaining his failure to follow a decision, made three months earlier by a different judge in the same court. In Re Tiokobule Bero, ${ }^{118}$ Brown J had held that the Adoption Act 1958 (UK) was not an Act of general application, despite the long history of granting applications under that Act in Solomon Islands. ${ }^{119}$ In holding that the Adoption Act 1958 (UK) was an Act of general application, Palmer CJ expressed regret that Brown $\mathrm{J}$ "did not have access to other previous decisions on the subject in particular in relation to the words 'Acts of

111 Christian $v$ R, above n 56, 409 (PC).

112 Ibid, 410, citing Nyali Ltd v Attorney-General [1956] 1 QB 1, 17.

113 The author has personal experience of the difficulty of advising clients as to their legal position where United Kingdom legislation had some potential bearing, from her time in practice in Solomon Islands between 1987 and 1996.

114 Anthony Allott New Essays in African Law (Butterworths, London, 1970) 48.

115 Bird $v$ The Registrar of Titles [1980-81] SILR 47.

116 Pitt v Lord Dacre (1876) 3 Ch D 295.

117 Above n 54.

118 (27 July 2007) unreported, High Court of Solomon Islands, Brown J.

119 See, eg, Re V [1985-1986] SILR 252; Re S (30 July 1999) unreported, High Court of Solomon Islands, Palmer J, Re S (31 August 2001) unreported, High Court of Solomon Islands, Kabui J. 
general application,"' which, in effect meant that the case was decided per incuriam. For the couple whose application to adopt was refused in Re Tiokobule Bero, this would be of little consolation.

Further, the reception rule's requirement that United Kingdom legislation be compatible with the lexically prior constitution and local statute law raises uncertainties, even if these uncertainties are typical of questions of inconsistent legislative provisions common to all legal systems. Interpretation of the constitution is a particularly complex task, especially as it includes a Bill of Rights and a Preamble or Pledge and Declaration that may be viewed more as a manifesto than a set of rules. Accordingly, in areas that are covered by general, vague or ambiguous provisions of the constitution, it may be difficult to predict before adjudication whether United Kingdom legislation will be applicable. ${ }^{120}$

As the above examples all show, until a judicial determination is made by a regional court, the number and texture of conditions within the reception rule make it difficult to assess the applicability of any United Kingdom statute in force before the cut-off date for the country in question. ${ }^{121}$ This results in the inability to predict in advance whether a particular foreign Act applies. This is discussed further under the next heading.

\section{Notice and Retrospectivity}

A particular aspect of certainty is the need for the legal profession and the public to be able to ascertain the law in force at any time. The ad hoc approach of considering whether foreign Acts are of general application and therefore in force, on an individual basis, as the question arises before a court, means that this is not possible until after judicial declaration on point. This is obviously objectionable from the point of view of both policy and practice. It may be particularly objectionable in the case of a criminal law, where a person may find him or herself liable to punishment for conduct contravening a statute that had not been declared to apply at the time of the conduct. This retrospective application of the law is contrary to international human right standards ${ }^{122}$ and to specific provisions in some regional constitutions. ${ }^{123}$ The problem was well illustrated in the Pitcairn case. As discussed above, the Sexual Offences Act 1956 (UK) had not been published in Pitcairn, and a copy was not available until about 1997. ${ }^{124}$ Although the law of

120 There are no reported cases on this, but it is a 'live' issue for lawyers in Solomon Islands.

121 Jennifer Corrin Care "Colonial Legacies?" in Jennifer Corrin Care (ed) Sources of Law in the South Pacific (1997) 21 Journal of Pacific Studies 43-54.

122 European Convention on Human Rights and Fundamental Freedoms, art 7 (entered in to force 3 September 1953)

123 See, for example, Constitution of Kiribati 1979 (UK), s 10(4); Constitution of Tonga Cap 2 (Tonga) cl 20.

124 The Privy Council found that the Pitcairn Order 1970 only required publication of legislation made locally by the Governor and not of statutes of general application: Christian $v R$, above $\mathrm{n} 55,410-411$. See further Helen Power, 'Pitcairn Island: Sexual Offending, Cultural Difference and Ignorance of the Law', [2007] Criminal Law Review 609. 
Pitcairn did not require publication of Acts of general application for them to be in force, a more general argument relating to notice found some favour. It was argued that it was a requirement of almost every modern system of criminal law, that persons be given actual or, at least, constructive notice of a criminal statute by which they were intended to be bound. The argument did not succeed in that case, as it was found that the accused were aware that their conduct was contrary to the criminal law and could have obtained detailed information relating to the Act under which they were charged if they had wanted to. However, Lord Woolf held, obiter, that he had no difficulty with "the generality of this freestanding argument." His Lordship agreed with the Supreme Court that governments must ensure adequate publication or at least reasonable access to the criminal laws which they wish to enforce. This his Lordship regarded as: ${ }^{125}$

a requirement of the rule of law, which in relation to the criminal law reflects the need for legal certainty

.... To prosecute an individual for an offence of which he has no means of knowing the details is capable

of being such a departure from the requirements of due process as to justify the prosecution being

stayed.

Lord Hope agreed, stating that "the requirement of ascertainability is an essential component of the rule of law". ${ }^{126}$ However, His Lordship went further, referring to the rule of law and to Thomas Hobbes statement that a good law is "withal perspicuous". ${ }^{127}$ He also commented that, "in the case of statutes of general application in force in England" that requirement "was incapable of being met" on Pitcairn

\section{Inaccessibility}

One aspect of the requirement of notice is the question of access. Even if the application of a law is not in doubt, this is of little use if it is inaccessible. Inaccessibility of the law has long been an issue in the South Pacific. Short print runs and shortage of resources has often led to difficulties in gaining access to local laws. The problem is more acute where foreign statutes apply. As illustrated in the Christian case, such legislation may, at times, not be available anywhere in the country where those laws are applied or adopted.

The problem is exacerbated in some former dependencies of Australia and New Zealand where, in addition to complying with the normal reception rules, the United Kingdom Act must be consistent with the laws of the former administering country, ${ }^{128}$ or in force there prior to a the date

125 Christian $v R$, above n 56, para 40

126 Christian $v R$, above $n$ 56, para 81

127 Leviathan (1651) ch 30, para 20, Christian v R, above n 56, para 87.

128 See, for example, Customs and Adopted Laws Act 1971 (Nauru) s 5(1), which requires the English statute to be consistent with any law of the Commonwealth of Australia, the State of Queensland, the Territory of Papua or the Territory of New Guinea in force in Nauru in order to apply. 
of adoption. ${ }^{129}$ The problem of accessibility is not cured by incorporation, as reference to the overseas statute books is still required to identify the content of the law. Only if the law is patriated is it made accessible in the same way as local legislation. Law reform agencies state that one of their primary aims is to make the law more accessible. For legislation, this includes reducing the number of different sources from which applicable statutes must be extracted. ${ }^{130}$

Whilst access to laws is not expressly required by bills of rights entrenched in local constitutions, as mentioned by the Court of Appeal of Pitcairn in the Christian case, human rights jurisprudence recognises the need for the public to have the means of ascertaining the existence and content of laws applicable to them, as well as reasonable or sensible access to those laws. ${ }^{131}$ Although the Court of Appeal did not regard this jurisprudence as supporting an argument that a law had to be published locally in order to be in force, ${ }^{132}$ it did consider knowledge and accessibility to be relevant to the question of whether an Act could be fairly enforced. ${ }^{133}$

\section{E Antiquation}

Over time, the reliance on applicable foreign legislation progressively enlarges a problem of antiquation. Residual paramount operation, reception and incorporation petrify the content of United Kingdom legislation applicable in South Pacific countries, as of their respective cut-off dates. ${ }^{134}$ Accordingly, reforms made in the foreign country after the cut-off dates to legislation potentially applicable in the South pacific country do not apply there. Thus, legislation identified as deficient in the foreign country continues in force in the region with those deficiencies uncorrected. ${ }^{135}$

129 See, for example, Cook Islands Act 1915 (NZ) s 615, applying by virtue of the Constitution of Cook Islands 1964, Art 77, whereby the law of England is only in force if it is also in force in new Zealand on 1 April 1916 (the date when the 1915 act came into force).

130 Australian Capital Territory Law Reform Commission, Imperial Acts in Force in the Australian Capital Territory, above n 20, 1; New Zealand Law Commission, Imperial Legislation in Force in New Zealand: Report No 1, above n 20, 1.

131 (2 March 2006) unreported, Court of Appeal, Pitcairn, Henry P Barker JA Salmon JA. See further, Anthony Trenwith "The Empire Strikes Back: Human Rights and the Pitcairn Proceedings" (2003) 7 (2) JSPL Working Paper.

132 See, for example, Blackpool Corporation v Locker [1948] 1 KB 349.

$133 R$ v Christian (PICA), above n 12, para 41.

134 Jennifer Corrin Care "Colonial Legacies?" in Jennifer Corrin Care (ed) Sources of Law in the South Pacific (1997) 21 Journal of Pacific Studies 51-2.

135 For example, the Matrimonial Causes Act 1950 (UK) still applies in Solomon Islands to expatriates and indigenous people married to expatriates, but was repealed in the UK in 1965: Matrimonial Causes Act 1965 (UK), s 45, sch 2. 


\section{F Post-independence legal dependence and Undesirability of Relying on Legal Transplants}

The system of reliance on the application of a former metropole's laws, rather than legislation specifically designed for Pacific peoples and circumstances, perpetuates post-independence legal dependence. The process of enactment allows for Acts to be tailored specifically for the country in which they are passed after debate informed by the views of a wide range of local stakeholders. In addition to being developed out of context, introduced laws are imposed on pre-existing systems of custom and culture. Introduced legislation may differ radically from customary law both in relation to substantive rules, procedure to be followed, the relief that may be granted and the penalties that may be imposed. It has been argued by Kahn-Freund that the success of transplant depends on the type of law involved, with public laws being the least likely to succeed due to their cultural specificity. ${ }^{136}$ Given that these are the very laws most likely to qualify as of "general application", ${ }^{137}$ this is another objection to the continuing application of such legislation.

\section{CONCLUSION}

The problems discussed in the foregoing paragraphs and highlighted in regional case law demonstrate the great importance of the patriation work done by Professor Angelo. In Niue and Tokelau, as a result of the patriation exercise, it is no longer necessary to struggle with the issues raised by the reception rules. ${ }^{138}$ The clear intention of all countries of the region on attaining independence was that adopted foreign legislation would only remain in force as a transitional step, to avoid a vacuum, whilst the new legislatures had the chance to enact laws suited to local circumstances. This is no doubt why a cut-off date was inserted for legislation, after which legislation passed overseas was not part of the law. However, whilst local legislation is gradually replacing introduced legislation, in some countries this has been a very slow process. The potential application of a large body of United Kingdom legislation creates a fundamental problem in regional legal systems, particularly as the cut-off date recedes into the past and residual paramount operation, reception and incorporation petrify the content of that legislation at that date. ${ }^{139}$ As legislative reforms in the country where the law legislation originated, made after the cut-off date,

136 O Kahn-Freund "Uses and Misuses of Comparative Law" (1974) 37 MLR 1, 5-6.

137 See, for example, Indian Printing and Publishing Co $v$ The Police (1932) 3 Fiji LR 142.

138 In Tokelau, related questions may arise in relation to common law and equity, but in Niue the English common law is was replaced by the common law of Niue as part of the patriation exercise: Interpretation Act 2004 (Niue) ss 4(e) and 37(4).

139 Jennifer Corrin Care "Colonial Legacies?" in Jennifer Corrin Care (ed) Sources of Law in the South Pacific, (1997) 21 Journal of Pacific Studies 51-52. 
do not apply in the receiving or adopting country, legislation identified as deficient in the country of origin continues in force in the region with those deficiencies uncorrected. ${ }^{140}$

Further, the uncertainties surrounding the exact ambit of British legislation in force leaves a wide scope for litigation. ${ }^{141}$ These uncertainties form a barrier to the establishment of an effective legal system and, on a broader level, an effective rule of law. ${ }^{142}$

However, this is not to suggest that all is doom and gloom. Fiji, Papua New Guinea and Solomon Islands ${ }^{143}$ have active law reform commissions. Samoa and Vanuatu, which have had provision for law reform commissions for some time, ${ }^{144}$ are bringing those bodies into operation. Moreover, there are signs of greater cooperation amongst those bodies under the umbrella of the Australasian Law Reform Agencies. In this environment, there is scope for tackling common problems and overcoming lack of resources, ${ }^{145}$ and for patriation to move up the agenda. The work on patriation carried out by Professor Angelo provides a model that all countries might benefit from.

140 For example, the Matrimonial Causes Act 1950 (UK) still applies in Solomon Islands to expatriates and indigenous people married to expatriates, but was repealed in the UK in 1965: Matrimonial Causes Act 1965 (UK), s 45, sch 2.

141 As Sir Kenneth Roberts-Wray observed, Commonwealth and Colonial Law, above n 9, 547: "The qualifications, referable to local circumstances, subject to which English law is applied generally, leave a wide field for litigation."

142 Fuller, above n 110, 39; Rawls, above n 110, 235.

143 Fiji Law Reform Commission Act, Cap 26; Law Reform Commission Act 1975 (Papua New Guinea); Law Reform Commission Act Cap 15 (Solomon Islands).

144 Law Reform Commission Act 2002 (Samoa); Law Commission Act Cap 115) (Vanuatu).

145 See, for example, the Law Reform Commission of Solomon Islands, Annual Report (No 2) 1996, Honiara, 10-11. This reveals that no work has been done on the 1995 reference to the Commission, requesting a report on the Acts applying and the need for modernisation due to 'lack of research officers'. The Law Reform Commission has since received substantial assistance through RAMSI and is functioning very effectively. 
